\title{
Report of Dirofilaria immitis infection with acute cardiopulmonary complications in a cat from Northeastern Brazil
}

\author{
Relato de infecção por Dirofilaria immitis com complicações \\ cardiopulmonares agudas em um gato no Nordeste do Brasil
}

\author{
Marcela Figuerêdo Duarte Moraes ${ }^{1}$; Andressa de Souza Pollo ${ }^{1}$; Kayana Cunha Marques²; Rayr César de Souza Góis ${ }^{2}$; \\ Mirlla Baracho Ferreira ${ }^{2}$; Alessandra Moreira da Silva²; Rivaldo Bruno Medeiros de Lucena²; Jael Soares Batista²; \\ Kilder Dantas Filgueira' ${ }^{2,3}$ (D); Fábio Parra Sellera ${ }^{3}$; Archivaldo Reche-Júnior³; Estevam Guilherme Lux Hoppe ${ }^{1}$ \\ ${ }^{1}$ Universidade Estadual Paulista, Faculdade de Ciências Agrárias e Veterinárias, Departamento de Patologia, Reprodução Animal e Saúde \\ Única, Jaboticabal - SP, Brazil \\ ${ }^{2}$ Universidade Federal Rural do Semiárido, Hospital Veterinário, Mossoró - RN, Brazil \\ ${ }^{3}$ Universidade de São Paulo, Faculdade de Medicina Veterinária e Zootecnia, Departamento de Clínica Médica, São Paulo - SP, Brazil
}

\begin{abstract}
Dirofilariasis is a zoonotic disease caused by Dirofilaria immitis, a nematode found mainly in the pulmonary artery and right chambers of the heart, lungs, and large vessels of dogs. This parasitism also occasionally occurs in cats, causing an amicrofilaremic and asymptomatic infection, resulting in severe illness and rapid death. In this case report, it was described acute clinical signs and histopathological alterations in a domestic cat with heartworm disease from the city of Mossoró, the Rio Grande do Norte, Brazil. The nematode species, D. immitis, was confirmed by morphological and molecular analyses. This is the first documented and full report of feline heartworm disease in northeastern Brazil.
\end{abstract}

Keywords: Parasitic diseases. Onchocercidae. Heartworm. Dirofilariasis.

\section{RESUMO}

A dirofilariose é uma doença zoonótica causada por Dirofilaria immitis, um nematódeo que parasita cães, principalmente a artéria pulmonar e as câmaras direitas do coração, pulmões e grandes vasos. Este parasita também ocorre ocasionalmente em gatos, geralmente causando uma infecção amicrofilarêmica e assintomática, que pode resultar em doença grave e morte rápida. Neste relato de caso, são apresentados os sinais clínicos agudos e alterações histopatológicas em um gato doméstico do município de Mossoró, Rio Grande do Norte, Brasil, com dirofilariose. A espécie de nematóide, $D$. immitis, foi confirmada por análises morfológicas e moleculares. Este é o primeiro relato documentado e completo de dirofilariose felina no Nordeste do Brasil.

Palavras-chave: Doenças parasitárias. Onchocercidae. Verme cardíaco. Dirofilariose. 
Correspondence to:

Kilder Dantas Filgueira

Universidade de São Paulo, Faculdade de Medicina Veterinária

e Zootecnia, Departamento de Clínica Médica

Av. Prof. Dr. Orlando Marques de Paiva, 87, Cidade

Universitária

CEP: 05508-270, São Paulo - SP, Brazil

e-mail: kilder@usp.br

Received: June 11, 2021

Approved: September 28, 2021

How to cite: Moraes MFD, Pollo AS, Marques KC, Góis RCS, Ferreira MB, Silva AM, Lucena RBM, Batista JS, Filgueira KD, Sellera FP, Reche-Júnior A, Hoppe EGL. Report of Dirofilaria immitis infection with acute cardiopulmonary complications in a cat from Northeastern Brazil. Braz J Vet Res Anim Sci. 2021;58:e186835. https://doi.org/10.11606/ issn.1678-4456.bjvras.2021.186835

\section{Introduction}

Dog heartworm (Dirofilaria immitis) is an important Onchocercidae nematode with worldwide distribution. This parasite affects the heart and large vessels of dogs, wild carnivores, and pinnipeds (Alho et al., 2017; Otranto \& Deplazes, 2019). Other animals, such as domestic cats and ferrets, are also susceptible to D. immitis infection (Ames, 2018). However, most of the larvae of this nematode do not reach their adult form in these hosts, as it is better adapted to dogs (Lee \& Atkins, 2010).

In cats, the death of D. immitis larvae results in an intense inflammatory response related to Wolbachia spp. endosymbiosis, which can be responsible for early signs of heartworm infection, also known as heartworm-associated respiratory disease. This stage of the disease may be mistakenly confused with feline asthma. Domestic cats have potentially life-threatening complications when infected by $D$. immitis, but unlike what happens in dogs, right-sided heart failure and vena cava syndrome have been rarely documented in these animals (McCall et al., 2008). Thus, this case report aimed to describe a cat from the city of Mossoró, Rio Grande do Norte State, in the Brazilian Caatinga Biome, with acute cardiopulmonary complications due to natural infection by $D$. immitis.

\section{CASE REPORT}

A one-year-old, $3.5-\mathrm{kg}$, neutered, male mixed-breed cat was admitted for emergency clinical care at the Veterinary Hospital of the Universidade Federal Rural do Semi-Árido (UFERSA), Mossoró city, Rio Grande do Norte State, Brazil. The animal was native to the region and had spent most of his time outside the house, and therefore in contact with other cats, and was not vaccinated, not dewormed, and fed ad libitum with commercial cat food and natural food. Two days before the hospital admission, he presented acute dyspnea, anorexia, and oligodipsia with acute onset. Neutering had been performed seven days before the onset of symptoms. On physical examination, the animal was placed in a sternal position with apatic behavior. The cat was hypothermic, and the heart auscultation revealed hypophonesis of the heart and pulmonary sounds and the probable presence of pleural effusion. The animal showed restrictive expiratory dyspnea, concomitant with superficial tachypnea. Other semiological changes were not observed. The patient was very excited at the time of the physical examination, avoiding excessive manipulation. It is not possible to carry out complementary exams, such as blood count, serum biochemistry, or radiographs of the thoracic cavity.

Thoracocentesis was performed, and yellowish pleural effusion was extracted. Physicochemical analysis of the fluid demonstrated the presence of modified transudate. On the same day, the animal died and necropsy was performed.

A large amount of yellowish turbid liquid was observed in the thoracic cavity (Figure 1A). The lungs were reddish, compact, and foamy fluid was present in the trachea and bronchi. The macroscopic examination of the heart revealed thin and flaccid, with right ventricular and atrial enlargement. A single specimen of an elongated whitish nematode was found in the right ventricle and atrium with morphology suggestive of $D$. immitis (Figure 1B). This nematode was collected, stored in absolute ethanol, and sent for taxonomic identification and molecular characterization.

The nematode was a mature adult female, measuring $11 \mathrm{~cm}$ in length, with a thin and rounded cephalic extremity and posterior part slightly curved. Its cuticle presented a delicate transversal striation along the entire nematode body. The oral opening was rounded, without visible lips. The nerve ring was located at the beginning of the esophagus, at $260 \mu \mathrm{m}$ from the anterior ending. Excretory pore was not observed. The esophagus was divided into muscular and glandular portions, but without a clear distinction between them, measuring $610 \mu \mathrm{m}$ in length. The width of the body at the esophageal-intestine junction was $460 \mu \mathrm{m}$. The vulvar opening was elongated, without any cuticular ornamentation, located at $1.61 \mathrm{~mm}$ from the anterior ending. The anus was simple and subterminal, at $170 \mu \mathrm{m}$ from the tail tip. The morphological analysis confirmed the nematode species as D. immitis (Figures 1C and D). 

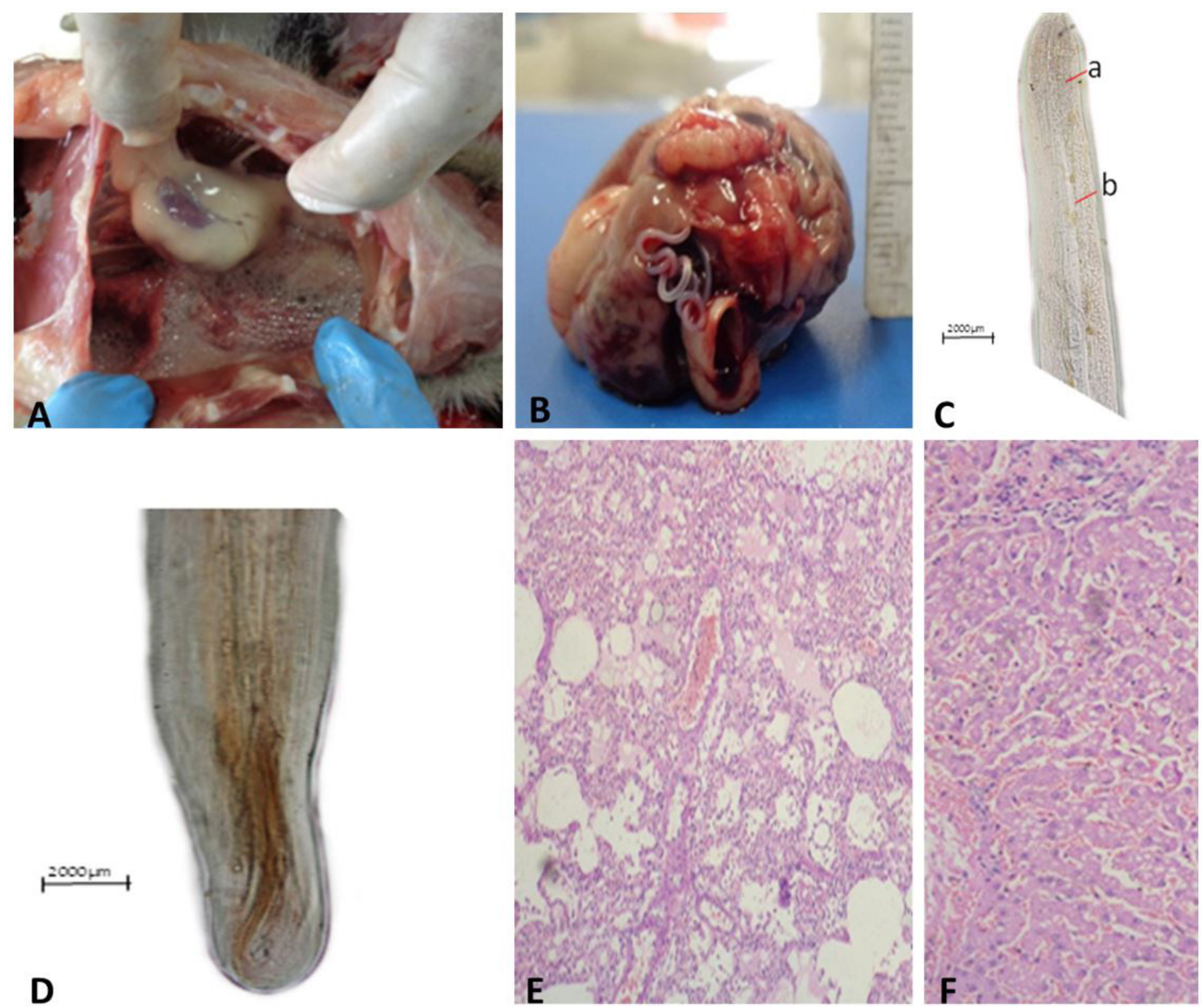

Figure 1 - Necroscopic findings, parasite morphological analysis, and histopathological alterations of a domestic cat parasitized by Dirofilaria immitis in the city of Mossoró, Rio Grande do Norte State, Brazil. (A) Thoracic cavity with yellowish turbid fluid; (B) Right atrium presenting an elongated parasite, suggestive of D. immitis; (C) Microscopic examination showing the anterior end of the adult female D. immitis - a. nerve ring, and b. esophagus; (D) Microscopic examination showing the posterior end of the D. immitis specimen; (E) Histopathological results of the lungs demonstrating interstitial edema; (F) Histopathological results of the liver demonstrating hepatic lipidosis.

Histopathological results showed interstitial edema and peribronchial mononuclear cell infiltrates in the lungs (Figure 1E). Areas of the right heart chambers showed muscle fibers slightly disorganized, but the endocardium remained unchanged. The liver presented mild to moderate lipid vacuolation in the cytoplasm of hepatocytes (Figure 1F). The other organs did not present histopathological alterations. The histopathological diagnosis was chronic bronco-interstitial pneumonia, bronco-interstitial and alveolar pulmonary edema, and hepatic lipidosis (Figure 1).

Nematode DNA was extracted using the protocol proposed by Bag et al. (2016). A DNA sample was submitted to amplification of the $18 \mathrm{~S}$ rDNA region by using the primers 1813F/2646R (Holterman et al., 2006). MyoHC and $h s p 70$ housekeeping genes were amplified using the primers designed by Lefoulon et al. (2015). The amplicons obtained were sequenced in the ABI3130 sequencer (Applied Biosystems). Generation of consensus sequences of each genomic region amplified and sequence trimming was performed by using the Phred/Phrap/Consed (Gordon et al., 1998). The sequences of $18 \mathrm{~S} \mathrm{rDNA}$ (505 bp), myoHC (390 bp), and $h s p 70$ (371 bp) of the nematode and sequences from the GenBank were aligned separately, using the tool MUSCLE (Edgar, 2004). The aligned sequences of the three genomic 
regions were concatenated, and a phylogenetic Bayesian analysis was performed using the MrBayes 3.2.3 software (Ronquist \& Huelsenbeck, 2003). The analysis was performed using the best fit model $\operatorname{Tr} \mathrm{N}+\mathrm{I}+\mathrm{G}$, according to the Akaike Information Criterion (AIC) (Posada \& Buckley, 2004), in four chains with 1,000,000 generations.

The phylogenetic analysis of the $18 \mathrm{~S}$ rDNA, myoHC, and $h s p 70$ genes concatenated datasets were compatible with D. immitis (Figure 2). The accession numbers of the sequences used in this study are presented in Table 1.

\section{Discussion}

Feline heartworm disease has been reported in many parts of the world, but its particularities are less known in cats than in dogs. This is because definitive ante-mortem diagnosis is difficult to achieve, and most feline dirofilariasis infections are asymptomatic. Therefore, the real prevalence of this disease in cats is underestimated in endemic areas (Venco et al., 2008). Unlike in dogs, microfilariae are produced only in $20 \%$ of cats with mature female and male worms, whereas they usually remain only a few months in

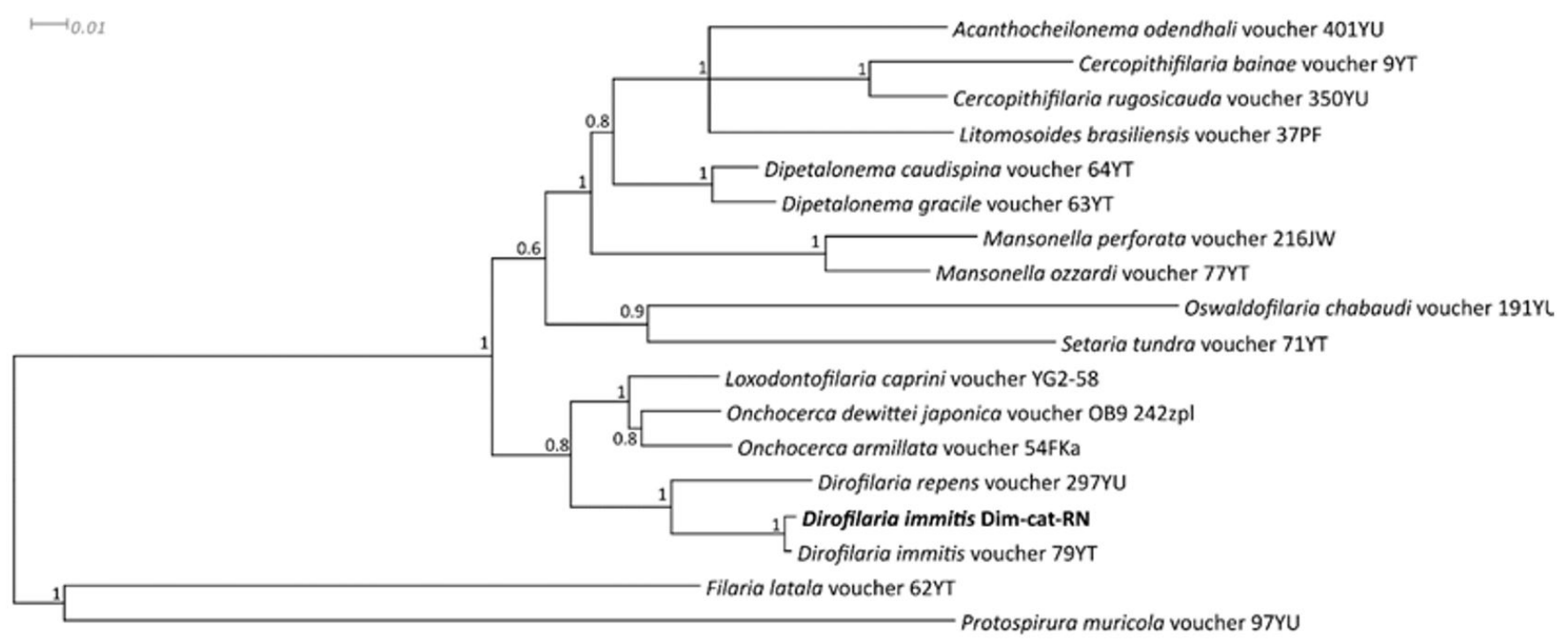

Figure 2 - Bayesian phylogenetic tree of concatenated 18S rDNA, myoHC, and hsp 70 sequences of the evaluated Dirofilaria immitis specimen (in bold) in comparison with other Onchocercidae nematodes. Protospirura muricola and Filaria alata were used as outgroups.

Table 1 - Accession numbers of Onchocercidae sequences of $18 \mathrm{~S}$ rDNA, myoHC, and hsp 70 genes were used in the phylogenetic analysis

\begin{tabular}{|c|c|c|c|c|}
\hline Onchocercidae species & Code & 18S rDNA & myoHC & hsp70 \\
\hline Acanthocheilonema odendhali & $401 \mathrm{YU}$ & KP760116 & KP760212 & KP760410 \\
\hline Cercopithifilaria bainae & 9YT & KP760123 & KP760219 & KP760417 \\
\hline Cercopithifilaria rugosicauda & $350 \mathrm{YU}$ & KP760124 & KP760220 & KP760418 \\
\hline Dipetalonema caudispina & $64 Y \mathrm{~T}$ & KP760127 & KP760223 & KP760421 \\
\hline Dipetalonema gracile & 63YT & KP760130 & KP760226 & KP760424 \\
\hline Dirofilaria immitis & 79YT & KP760133 & KP760229 & KP760427 \\
\hline Dirofilaria immitis & Dim-cat-RN & MW010021 & MW036532 & MW036533 \\
\hline Dirofilaria repens & $297 Y U$ & KP760134 & KP760230 & KP760428 \\
\hline Filaria latala & $62 Y T$ & KP760135 & KP760231 & KP760429 \\
\hline Litomosoides brasiliensis & 37PF & KP760140 & KP760236 & KP760434 \\
\hline Loxodontofilaria caprine & YG2-58 & KP760144 & KP760240 & KP760438 \\
\hline Mansonella perforata & 216JW & KP760145 & KP760241 & KP760439 \\
\hline Mansonella ozzardi & 77YT & KP760147 & KP760243 & KP760441 \\
\hline Onchocerca armillata & 54FKa1 & KP760153 & KP760248 & KP760446 \\
\hline Onchocerca dewittei japonica & OB9 242zpl & KP760154 & KP760249 & KP760447 \\
\hline Oswaldofilaria chabaudi & $191 \mathrm{YU}$ & KP760159 & KP760254 & KP760452 \\
\hline Protospirura muricola & $97 Y U$ & KP760162 & KP760257 & KP760455 \\
\hline Setaria tundra & $71 Y \mathrm{~T}$ & KP760165. & KP760260 & KP760458 \\
\hline
\end{tabular}


circulation and at a low number of specimens (Ciuca et al., 2020).

In Europe, the prevalence of feline dirofilariasis varies between different regions. In Barcelona, Spain, it corresponds to about $10 \%$ of the prevalence in dogs within the same area (Venco et al., 2011). In the metropolitan area of Zaragoza, also in Spain, the seroprevalence of $D$. immitis in the feline population corresponds to $25.2 \%$ (Villanueva-Saz, et al., 2021). In Romania, dirofilariasis prevalence varied from 13.4\% to 23.0\% (Anghel et al., 2016; Girdan et al., 2015; Ionita et al., 2012; Pana et al., 2018). In Tuscany, Italy, it was about 24.9\% (Magi et al. 2002) and in the central and northern regions of Portugal, $15.0 \%$ of the evaluated cats presented anti-D. immitis and anti-Wolbachia antibodies (Vieira et al., 2015). A higher prevalence of dirofilariasis in cats has been reported in Central and South America, with $42 \%$ being found in the cities of the Gulf Coast of Mexico, and $63.2 \%$ in the Caribbean region (Bahamas, Curaçao, Cuba, the Dominican Republic, and Puerto Rico). In Florida, necropsies performed on 630 adult cats revealed the presence of heartworms in $4.9 \%$ of the animals, with serological evidence of heartworm pre-exposure in $17 \%$ of the tested population (Levy et al., 2003).

In South America, some studies have reported lower levels of exposure in cats living in areas where canine dirofilariasis is endemic. Therefore, the risk of $D$. immitis infestation in cats within the same geographic area may partly vary (Dantas-Torres \& Otranto, 2013). Indeed, information about the geographical distribution and epidemiological features of $D$. immitis infection in cats is scarce, particularly in the urban stray cat population living in endemic regions for canine heartworm disease (VillanuevaSaz et al., 2021). Specifically in Brazil, there are only two reports of feline heartworm disease (Alberigi et al., 2020; Branco et al., 2009), and both occurred in Rio de Janeiro State, southeastern Brazil.

Histological alterations in the lungs of the studied cat were marked by the presence of eosinophil infiltrates in the parenchyma, pulmonary vasculature, and air spaces, due to pneumonitis caused by the parasite. The pronounced bronchial reactivity was due to the activity of pulmonary intravascular macrophages, a component of the reticuloendothelial system in cats (Dillon et al., 2008).

Acute death of asymptomatic heartworm-infected cats has been widely reported (Holmes, 1993; Dillon, 1984; Ralston et al., 1998), and it has been attributed to acute pulmonary thromboembolism due to spontaneous death of the adult heartworms (Dvorak et al., 2000). The present case showed only one adult heartworm in the right ventricle and atrium, without any obstruction of large vessels, even though clinical signs of dyspnea were observed due to pleural effusion that probably resulted from the inflammatory response of the lungs (Litster \& Atwell, 2006). The pulmonary inflammatory process leads to changes in vascular permeability, resulting in the extravasation of proteinaceous fluid from the intravascular environment into the thoracic cavity, causing fluid accumulation (Ames, 2018), which could have justified the origin of the observed pleural effusion. Severe dyspnea, along with reduced blood oxygen saturation and decreased blood pressure are the main signs of $D$. immitis infection in cats (Litster \& Atwell, 2006). The dirofilariasis in cats is primarily a lung disease (even adopting a new designation: dirofilariasis-associated respiratory disease), so the main morphological changes are those related to the lungs (Nelson, 2012). Such citation can justify, for the present case, the predominance of histopathological alterations directed to the lungs. The parasite causes an intense inflammatory reaction and thromboembolism, which can lead to acute lung injury. There is subsequent hyperplasia of alveolar cells, which sometimes causes permanent lung dysfunction. Inflammation is enough to constrict the small airways in the lungs (Nelson, 2012).

In the GenBank, there is a lack of $D$. immitis sequences, as well as observed for other Onchocercidae nematodes. The sequencing of the $18 \mathrm{~S}$ rDNA region alone is not enough for the specific identification of Onchocercidae nematodes (Lefoulon et al., 2015). Thus, the use of molecular biology was important to detect the real existence of $D$. immitis in the studied cat and alert to the possibility of heartworm disease in the region in question, despite the absence of epidemiological surveys for such parasitic disease, in the feline population of the geography region reported. In the city of Mossoro (Rio Grande do Norte State, Brazil) there are only studies aimed at detecting $D$. immitis in dogs, revealing an incidence of $15 \%$ to $21 \%$, with such values coming from other diagnostic exams, such as Knott's test, immunoassay, and necropsy (Batista et al., 2008, 2021), with a lack of knowledge about the use of molecular methods to date. It is known that the prevalence of dirofilariasis in animals occurs more commonly in tropical or subtropical coastal regions, which have favorable climate, temperature, and humidity conditions for the perpetuation of potential vectors for the transmission of $D$. immitis, which corresponds to mosquitoes of the Culicidae family (Leite et al., 2006). The municipality of the report in question has a semiarid climate and is approximately $40 \mathrm{~km}$ away from the coastal areas. Therefore, the record of the case became somewhat uncommon, because the geographic location and the animal species affected are not usually related to 
the onset of dirofilariasis. For the case in question, since the animal is native to a city without a coastal strip, one of the transmission hypotheses could correspond to the presence of other mechanical vectors for $D$. immitis, which have not yet been identified.

\section{Conclusion}

In this case report, the signs observed at necropsy of this feline patient were probably caused by $D$. immitis, since the parasite was identified by morphological and molecular analyses of three genomic regions. Besides describing clinical signs of dirofilariasis in a cat this case report provided sequences of $D$. immitis that may contribute to molecular diagnostic of the parasite.

\section{References}

Alberigi B, Oliveira AC, Vieira GSR, Fernandes PA, Labarthe N, Mendes-de-Almeida F. Unusual feline Dirofilaria immitis infection: a case report. Rev Bras Parasitol Vet. 2020;29(3):e00842. http://dx.doi.org/10.1590/s198429612020061. PMid:32785525.

Alho AM, Marcelino I, Colella V, Flanagan C, Silva N, Correia JJ, Latrofa MS, Otranto D, Madeira de Carvalho L. Dirofilaria immitis in pinnipeds and new host record. Parasit Vectors. 2017;10(1):142. http://dx.doi.org/10.1186/ s13071-017-2073-0. PMid:28288690.

Ames MK. Heartworm disease. In: Hopper KJ, Rozanski E, Silverstein DC. Textbook of small animal emergency medicine. New Jersey, USA: Wiley; 2018. p. 362-71. http:// dx.doi.org/10.1002/9781119028994.ch58.

Anghel RG, Mitrea IL, Ionită M. Retrospective study on prevalence of canine vector-borne diseases in Bucharest area. Rev Rom Med Vet. 2016;26:27-32.

Bag S, Saha B, Mehta O, Anbumani D, Kumar N, Dayal M, Pant A, Kumar P, Saxena S, Allin KH, Hansen T, Arumugam M, Vestergaard H, Pedersen O, Pereira V, Abraham P, Tripathi R, Wadhwa N, Bhatnagar S, Prakash VG, Radha V, Anjana RM, Mohan V, Takeda K, Kurakawa T, Nair GB, Das B. An improved method for high-quality metagenomics DNA extraction from human and environmental samples. Sci Rep. 2016;6:26775. http://dx.doi.org/10.1038/srep26775. PMid:27240745.

\section{Conflict of Interests}

The authors declared no potential conflicts of interest concerning the research, authorship, and/or publication of this article.

\section{Ethics Statement}

The owner of the feline patient provided written informed consent for both diagnostic assessment and publication of this case report, with accompanying images.

\section{Acknowledgments}

This study was financed in part by the Fundação de Amparo à Pesquisa do Estado de São Paulo (FAPESP) (Proc. n. 2016/14886-9, and 2016/15589-8).

Batista JS, Batista AIV, Santos WLA, Pereira JS, Silva FHA, Félix NS, Lima GRF, Peterlinkar MC, Canela LAO, Mendes ABS, Carneiro NF, Rodrigues VHV. Macroscopic and histopathological changes in dogs parasitized by Dirofilaria immitis (Leidy, 1856) in Mossoró, Rio Grande do Norte, Brazil. In: Rodrigues VHV, organizer. Atualidades na saúde e bem-estar animal [Internet].Fortaleza: Editora In Vivo; 2021. Vol. 2; p. 24-35. https://doi.org/10.47242/978-65993899-0-0-3.

Batista NB, Bezerra NM, Gadelha ICV, Borges MEOB, Cabral SO, Dias CEV, Sakamoto SM, Freitas CIA. Utilização de kit comercial anigen rapid Dirofilaria immitis $\mathrm{Ag}^{\oplus} \mathrm{em}$ comparação com a técnica de knott modificada no diagnóstico da incidência de cães portadores da dirofilariose. Acta Vet Bras. 2008;2(3):76-9.

Branco AB, Mendes-de-Almeida F, Faria MCF, SouzaDantas LM, Labarthe NV. Dirofilaria immitis (Leidy, 1856) in the neighborhood of a feline case: a study about the transmission. Braz J Vet Parasitol. 2009;18(suppl. 1):14-8. http://dx.doi.org/10.4322/rbpv.018e1003.

Ciuca L, Roman C, Prisco F, Miron L, Acatrinei D, Paciello O, Maurelli MP, Vismarra A, Cringoli G, Rinaldi L. First report of Dirofilaria repens infection in a microfilaraemic cat from Romania. Vet Parasitol Reg Stud Reports. 2020;22:100497. http://dx.doi.org/10.1016/j.vprsr.2020.100497. PMid:33308740.

Dantas-Torres F, Otranto D. Dirofilariosis in the Americas: a more virulent Dirofilaria immitis? Parasit Vectors. 
2013;6:288. http://dx.doi.org/10.1186/1756-3305-6-288. PMid:24274042.

Dillon AR, Warner AE, Brawner W, Hudson J, Tillson M. Activity of pulmonary intravascular macrophages in cats and dogs with and without adult Dirofilaria immitis. Vet Parasitol. 2008;158(3):171-6. http://dx.doi.org/10.1016/j. vetpar.2008.09.004. PMid:18977090.

Dillon R. Feline Dirofilariasis. Vet Clin North Am Small Anim Pract. 1984;14(6):1185-99. http://dx.doi.org/10.1016/ S0195-5616(84)50153-3. PMid:6393552.

Dvorak LD, Preziosi DE, Hitchcock LS. What is your diagnosis? Acute pulmonary thromboembolism secondary to spontaneous death of adult heartworms. J Am Vet Med Assoc. 2000;217(2):180-1. http://dx.doi.org/10.2460/ javma.2000.217.180. PMid:10909454.

Edgar RC. MUSCLE: multiple sequence alignment with high accuracy and high throughput. Nucleic Acids Res. 2004;32(5):1792-7. http://dx.doi.org/10.1093/nar/gkh340. PMid:15034147.

Girdan G, Anghel RG, Ioniță M, Mitrea IL. Data on canine heartworm Dirofilaria immitis infection and other vectorborne pathogens in dogs in Bucharest area, Romania. Sci Works Ser C Vet Med (Univ Agron Sci Vet Med Buchar). 2015;61:146-51.

Gordon D, Abajian C, Green P. Consed: a graphical tool for sequence finishing. Genome Res. 1998;8(3):195-202. https://doi.org/10.1101/gr.8.3.195.

Holmes R. Feline heartworm disease. Compend Contin Educ Pract Vet. 1993;15:687-95.

Holterman M, van der Wurff A, van den Elsen S, van Megen $\mathrm{H}$, Bongers T, Holovachov O, Bakker J, Helder J. Phylumwide analysis of SSU rDNA reveals deep phylogenetic relationships among nematodes and accelerated evolution toward crown clades. Mol Biol Evol. 2006;23(9):1792-800. http://dx.doi.org/10.1093/molbev/msl044. PMid:16790472.

Ionita M, Enachescu V, Mitrea IL. Preliminary data on serological survey of exposure to arthropod-borne pathogens in stray dogs from Bucharest, Romania. Sci Works Ser C Vet Med (Univ Agron Sci Vet Med Buchar). 2012;58:220-4.

Lee AC, Atkins CE. Understanding feline heartworm infection: disease, diagnosis, and treatment. Top Companion
Anim Med. 2010;25(4):224-30. http://dx.doi.org/10.1053/j. tcam.2010.09.003. PMid:21147476.

Lefoulon E, Bain O, Bourret J, Junker K, Guerrero R, Cañizales I, Kuzmin Y, Satoto TB, Cardenas-Callirgos JM, De Souza Lima S, Raccurt C, Mutafchiev Y, Gavotte L, Martin C. Shaking the tree: multi-locus sequence typing usurps current onchocercid (filarial nematode) phylogeny. PLoS Negl Trop Dis. 2015;9(11):e0004233. http://dx.doi. org/10.1371/journal.pntd.0004233. PMid:26588229.

Leite LC, Cirio SM, Queiroz VS, Siva MAN, Luz E, Molinari HP, Diniz JMF, Leite SC, Lunelli D, Weber S, Zadorosnei ACB. Dirofilariose canina: revisão de uma zoonose emergente. Rev Acad (Pontif Univ Catól Paraná). 2006;4(4):49-56. http://dx.doi.org/10.7213/cienciaanimal.v4i4.9522.

Levy JK, Snyder PS, Taveres LM, Hooks JL, Pegelow MJ, Slater MR, Hughes KL, Salute ME. Prevalence and risk factors for heartworm infection in cats from northern Florida. J Am Anim Hosp Assoc. 2003;39(6):533-7. http:// dx.doi.org/10.5326/0390533. PMid:14736717.

Litster A, Atwell R. Physiological and haematological findings and clinical observations in a model of acute systemic anaphylaxis in Dirofilaria immitis-sensitised cats. Aust Vet J. 2006;84(5):151-7. http://dx.doi.org/10.1111/j.1751-0813.20 06.tb12768.x. PMid: 16739523.

Magi M, Sebastiani B, Bandecchi P, Prati MC, Guberti V. Seroprevalence of feline heartworm disease in Tuscany. Vet Rec. 2002;150(13):415-6. http://dx.doi.org/10.1136/ vr.150.13.415. PMid:11999281.

McCall JW, Genchi C, Kramer LH, Guerrero J, Venco L. Heartworm disease in animals and humans. Adv Parasitol. 2008;66:193-285. http://dx.doi.org/10.1016/S0065308X(08)00204-2. PMid:18486691.

Nelson CT. Heartworm disease. In: Greene CG. Infectious diseases of the dog and cat. Missouri, USA: Elsevier; 2012. p. 865-77.

Otranto D, Deplazes P. Zoonotic nematodes of wild carnivores. Int J Parasitol Parasites Wildl. 2019;9:370-83. http://dx.doi. org/10.1016/j.ijppaw.2018.12.011. PMid:31338295.

Pana D, Mitrea IL, Ionita M. Parasitological screening on canine dirofilariosis, Southern Romania: preliminary data. Rev Sci Parasitol. 2018;19:45-51. 
Posada D, Buckley TR. Model selection and model averaging in phylogenetics: advantages of Akaike Information Criterion and Bayesian approaches over likelihood ratio tests. Syst Biol. 2004;53(5):793-808. http://dx.doi. org/10.1080/10635150490522304. PMid:15545256.

Ralston S, Stemme K, Guerrero J. Preventing feline heartworm disease. Feline Pract. 1998;26(3):18-22.

Ronquist F, Huelsenbeck JP. MrBayes 3: bayesian phylogenetic inference under mixed models. Bioinformatics. 2003;19(12):1572-4. http://dx.doi.org/10.1093/bioinformatics/ btg180. PMid:12912839.

Venco L, Genchi C, Genchi M, Grandi G, Kramer LH. Clinical evolution and radiographic findings of feline heartworm infection in asymptomatic cats. Vet Parasitol. 2008;158(3):232-7. http://dx.doi.org/10.1016/j. vetpar.2008.09.011. PMid:18952375.

Venco L, Genchi M, Genchi C, Gatti D, Kramer L. Can heartworm prevalence in dogs be used as provisional data for assessing the prevalence of the infection in cats? Vet Parasitol. 2011;176(4):300-3. http://dx.doi.org/10.1016/j. vetpar.2011.01.013. PMid:21292401.

Vieira L, Silvestre-Ferreira AC, Fontes-Sousa AP, Balreira AC, Morchón R, Carretón E, Vilhena H, Simón F, Montoya-Alonso JA. Seroprevalence of heartworm (Dirofilaria immitis) in feline and canine hosts from central and northern Portugal. J Helminthol. 2015;89(5):625-9. http://dx.doi.org/10.1017/ S0022149X14000352. PMid:24824176.

Villanueva-Saz S, Giner J, Verde M, Yzuel A, González A, Lacasta D, Marteles D, Fernández A. Prevalence of microfilariae, antigen and antibodies of feline dirofilariosis infection (Dirofilaria immitis) in the Zaragoza metropolitan area, Spain. Vet Parasitol Reg Stud Reports. 2021;23:100541. http://dx.doi.org/10.1016/j.vprsr.2021.100541. PMid:33678394.

Financial Support: This study was financed in part by the Fundação de Amparo à Pesquisa do Estado de São Paulo (FAPESP) (Proc. n. 2016/14886-9, and 2016/15589-8). 